\title{
Effect of Viral Marketing, Promotions, Discounts and Store Atmosphere Purchase Decision (Case Study on Shoesholic Veteran Padang)
}

\author{
Alhafis Zahra ${ }^{1}$, Idris ${ }^{2}$ \\ 1Universitas Negeri Padang, Padang, Indonesia, $\triangle$ alhafiszahra95@gmail.com \\ 2Universitas Negeri Padang, Padang, Indonesia, $₫$ idris_unp@yahoo.co.id
}

\begin{abstract}
In this globalization era, the business world has entered a very tight competition. This competition appears along with the development of increasingly sophisticated technology, encourage a wide range of changes in the world system, either directly or indirectly. In the business world such as the system changes, the system in trading, marketing, transaction and information delivery method will change. The existence of a sophisticated technology with the Internet network facilitates direct interaction between consumers and businesses. And along with the development of increasingly sophisticated internet and spacious, businesses are now choosing a marketing strategy by utilizing the Internet to communicate, provide information and promote their business to the public or consumers. Research aims to study whether there is influence of the Effect of Viral Marketing, Promotions, Discounts and Store Atmosphere Purchase Decision (Case Study on Shoes Holic Veteran Padang), The method of determining the planned sample in this research is purposive sampling and observation data obtained 200 as a sample. The data used are primary data Year 2018. Observation of this study using multiple linear regression. The results showed there were significant and positive effect between viral marketing, promotions, discounts and store atmosphere on purchasing decisions.

Keywords: Viral Marketing, Promotions, Discounts and Store Atmosphere on Purchasing Decision
\end{abstract}

\section{Introduction}

Indonesia is a developing country, can be seen in this globalization era, the business world has entered a very tight competition. This competition appears along with the development of increasingly sophisticated technology, encourage a wide range of changes in the world system. Businesses are now choosing a marketing strategy by utilizing the Internet to communicate, provide information to the public and to promote their businesses or consumers. Business marketing activities by using the internet is called E-marketing. E-marketing is the marketing side of which consists of the company's work to communicate something, promote, and sell goods or services via the internet. This marketing system can reach a very large region or even the world, but it can also be done 24 hours without stopping. By simply connect the Internet, the company can market its products. From the development of the Internet was not separated from the social media phenomenon is increasingly widespread use communities and companies in influencing the business world.

Seeing the development of the Internet is becoming more sophisticated and competition getting tougher what more in fashion, sellers try to boost strategy of promotion through social media using techniques Viral Marketing, as seen this strategy is a promotional tool that is most effective to deploy communication faster than the promotional tools. According to Kotler and Armstrong (2012: 538), viral marketing is marketing the Internet version of the use of marketing by word of mouth through a website, video, e-mail message, or show other marketing was highly infectious that customers want to forward it to friends they.

According Skrob (2005)Viral marketing can be understood as communication and distribution concepts that rely on customers to submit digital products by electronic mail to other potential customers in the areas of social and to turn these contacts also send product Viral Marketing utilizes recommendation by friends and have a snowball effect, Viral Marketing is more powerful than other 
means of advertising because it conveys an implied endorsement from people you know. Viral Marketing is a strategy based on and taking advantage of the nature of these information disseminations on the internet like a virus, this type of marketing reproduces itself and the customer is the client disseminate it,

In addition to the promotions carried out by the company in support of the achievement of sales of both goods and services, accommodation is also one of the most important elements to support sales. Furthermore, to develop strategies to compete in an increasingly competitive market condition. Store environment has a very important role to attract consumers. Store atmosphere is one important element of a retail mix that can affect consumer buying decision process.

Referring to previous studies conducted by research conducted by Eltaj Mohammed, (2017) examines the Securities Investigation Against Viral Marketing Marketing Purchase Decision (Case Study: Students College- The Administrative Sciences Najran University. The study's findings indicate that there is a significant and positive relationship between viral Marketing marketing and purchasing decisions; In other words, viral marketing takes customers ketingkatkan their purchasing decisions.

Further research conducted by Cindy Juwita (2013) examines Store Atmosphere Effect on Consumer Purchasing Decisions in Texas Chicken Manado Multimart II. This study aimed to determine the effect of the Atmosphere of the Purchase Decision Stoe either collectively or individually, by means of multiple linear regression analysis, hypothesis testing using the $\mathrm{F}$ test and $\mathrm{T}$ test results show store exterior (X1), general interior (X2), store layout (X3) and the interior display (X4) significantly influence the purchase decision, but there are weaknesses in this study, the results of multiple linear regression test R Square of 0.709 , this shows that the influence of variable $X$ to $Y 70.9 \%$ while the rest influenced other variables outside variables examined in this study,

\section{Methods}

This study aimed to determine the effect of viral Marketing, Promotions, Discounts and Store Atmosphere on Purchasing Decision. The population in this study is that consumers who visit the store and using products Shoes Holic Padang with a sample of 200 respondents were selected based on non-probability sampling techniques. Criteria for selecting the sample in this study is that consumers who visit the store and using products Shoes Holic Veteran Padang. This research was conducted in 2019. The data analysis technique used is the analysis multiple linear regression.

\section{Results and Discussion}

Analysis multiple linear regression. is used to determine the effect of linearly between variables viral Marketing, Promotions, Discounts and Store Atmosphere onto the purchasing decision of data processing with SPSS 21.0 was obtained result as in the following table 1.

Based on the data below obtained linear equation as follows:

$$
\begin{aligned}
& Y=a+b 1 x 1+b 2 X 2+b 3 X 3+b 4 X 4+e \\
& Y=-16.891+0,457 X 1+0,271 X 2+0,479 X 3+0,342 X 4+e
\end{aligned}
$$

Table 1 Analysis Multiple Linear Regression

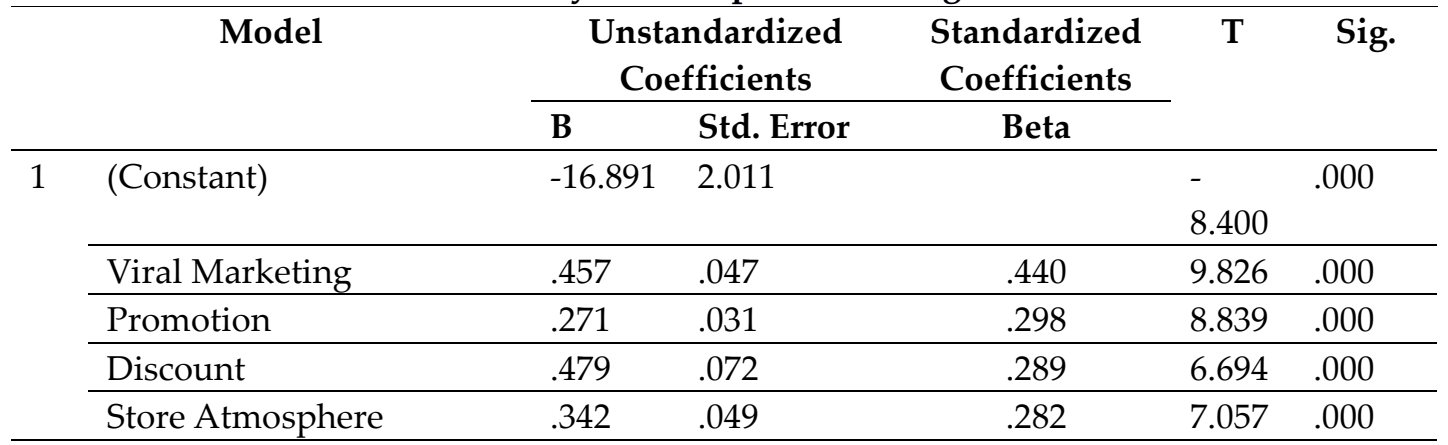

Source: primary data, 2019 
From Regression equations above, it can be interpreted as follows, the magnitude of the constants obtained at -16.891 shows, without any independent variables that viral marketing (X1), promotion $(\mathrm{X} 2)$, discount $(\mathrm{X} 3)$, and store atmosphere $(\mathrm{X} 4)$, then the value of the purchase decision $(\mathrm{Y})$ amounted to -16.891 . The regression coefficient (b) of the variable viral marketing (X1) obtained is positive, namely 0.457 indicates that any increase in the variable viral marketing one unit, it will result in an increase in the purchasing decision, amounting to 0.457 units. The regression coefficient (b) of the variable promotion $(\mathrm{X} 2)$ obtained is positive, namely 0.271 indicates that any increase in the variable promotion one unit, it will result in an increase in the purchasing decision, amounting to 0.271 units. The regression coefficient (b) of the variable discount (X3) obtained is positive, namely 0.479 indicates that any increase in the variable discount one unit, it will result in an increase in the purchasing decision, amounting to 0.479 units. The regression coefficient (b) of the variable store atmosphere $(\mathrm{X} 4)$ obtained is positive, namely 0.342 indicates that any increase in the variable store atmosphere one unit, it will result in an increase in the purchasing decision, amounting to 0.342 units.

\section{Hypothesis}

$\mathrm{F}$ test is to prove the significance level of all independent variables on the dependent variable. This research was used to examine the effect of viral marketing, promotions, discounts and store atmosphere against buying decision. Based on the calculation results of the ANOVA F test at the table as follows:

Table 2 F- test results

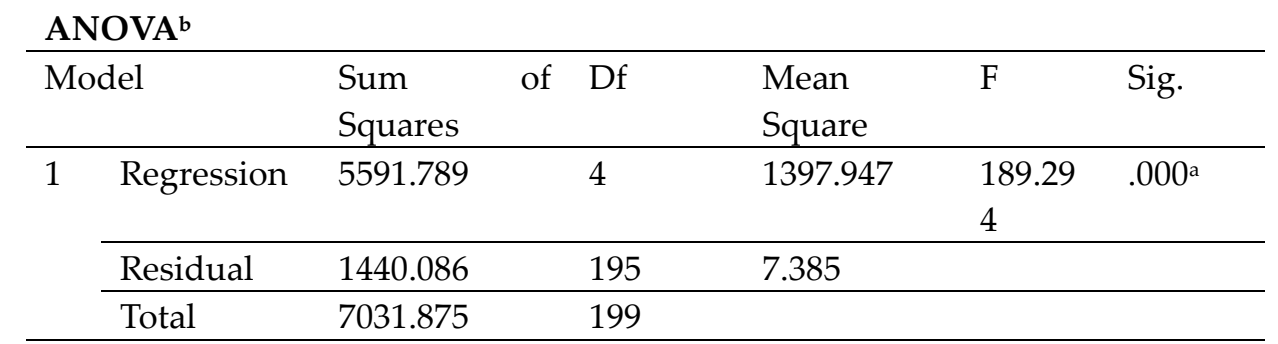

a. Predictors: (Constant), Store Atmosphere, Promotion, Discount, Viral Marketing

b. Dependent Variable: Purchase Decision

Source: primary data 2019

Based on the table above, obtained F count 189.294 with sig $0.000<0.05$. This means that of the $\mathrm{F}$ test conducted jointly exogenous variables have positive and significant influence on the purchase decision (Case Study on Shoes Holic Veteran Padang), meaning that the exogenous variables together have a positive and significant effect on endogenous variables.

\section{T-statistic}

\section{hypothesis 1}

viral marketing significant positive effect on the purchase decision (Case Study on Shoes Holic Veteran Padang). Based on the analysis of the test results are known tcount $>t$ table is $9.826>1.653$ (Sig. 0.000 $<0.05)$. meanH0 is rejected and Ha accepted, so the alternative hypothesis proposed in the study is accepted, that viral marketing significant positive effect on purchasing decisions (Case Study on Shoes Holic Veteran Padang).

\section{hypothesis 2}

Promotion significant positive effect on the purchase decision (Case Study on Shoes Holic Veteran Padang). Based on the analysis of the test results are known $t$ count $>t$ table is $8.839>1.653$ (Sig. 0.000 $<0.05)$. meanH0 is rejected and Ha accepted, so the alternative hypothesis proposed in the study is accepted, that promotion significant positive effect on purchasing decisions (Case Study on Shoes Holic Veteran Padang). 


\section{hypothesis 3}

Discount significant positive effect on the purchase decision (Case Study on Shoes Holic Veteran Padang). Based on the analysis of the test results are known $t$ count $>t$ table is $6.694>1.653$ (Sig. 0.000 $<0.05$ ). meanH0 is rejected and Ha accepted, so the alternative hypothesis proposed in the study is accepted, that discount significant positive effect on purchasing decisions (Case Study on Shoes Holic Veteran Padang).

\section{hypothesis 4}

Store atmosphere significant positive effect on the purchase decision (Case Study on Shoes Holic Veteran Padang). Based on the analysis of the test results are known $t$ count $>t$ table is 7.057> 1.653 (Sig. $0.000<0.05$ ). mean $\mathrm{H}_{0}$ is rejected and $\mathrm{Ha}$ accepted, so the alternative hypothesis proposed in the study is accepted, that store atmosphere significant positive effect on purchasing decisions (Case Study on Shoes Holic Veteran Padang).

\section{Results and Decisions}

\section{Effect of Viral Marketing on Purchasing Decision (Case Study on Shoes Holic Veteran Padang)}

This study proves that viral marketing has a significant positive effect on the purchase decision (Case Study on Shoes Holic Veteran Padang). The results of the study can be seen viral marketing coefficient of 0.457 and has no effect or a positive direction on purchasing decisions. The results show that with increasing Shoes Holic Veteran Padang do Viral Marketing will affect customers in making purchasing decisions in this regard Viral Marketing will also introduce Shoes Holic to new customers and will expand its market share, especially it is supported by users of social media in Indonesia is very much especially instagram it will be a factor Shoes Holic support in implementing viral marketing techniques to attract the attention of consumers,

This finding is consistent with that made by Eltaj Mohammed, (2017) examines the Securities Investigation Marketing viral Marketing Against Buying Decision (Case Study: The Student Administrative Sciences Najran University College-, The study's findings indicate that there is a significant and positive relationship between viral Marketing marketing and purchasing decisions

According to (Lekhanya, 2014) the term 'Viral Marketing' describes the phenomenon where consumers are interconnected to share and disseminate relevant information marketing was initially sent deliberately by the market to stimulate and harness the behavior of mouth. "In other words, viral marketing is a marketing strategy that focuses on the dissemination of information and opinions about a product or service from person to person, primarily by using unconventional means such as the Internet or email.

\section{Effect of Promotion on Purchasing Decision (Case Study on Shoes Holic Veteran Padang)}

This experiment proved that the promotion has a significant positive effect on the purchase decision (Case Study on Shoes Holics Veteran Padang). The results of the study can be viewed coefficient sale of 0.271 and has no effect or a positive direction on purchasing decisions. The results show that with increasing Shoes Holic Veteran Padang promotion will affect customers in making purchasing decisions in this promotion through social media will also introduce Shoes Holic to new customers and will expand its market share, especially it is supported by users of social media in Indonesia is very much especially instagram, facebook it Shoes will be a contributing factor in applying the technique Holic promotion through social media to attract the attention of consumers.

This finding is consistent with research conducted by Salome, Peter, et al. (2017) studied the "Multi-unit sale price and its impact on purchasing decisions and sales" used sample of 220 respondents. The results showed that the campaign significantly influence purchasing decisions and sales, promotional units, multiple units of a significant effect on sales, promotions leading to a number of higher purchase sales promotion led to a greater response. 


\section{Effect of Discount on Purchasing Decision (Case Study on Shoes Holic Veteran Padang)}

This study proves that discounts have a significant positive effect on purchasing decisions (Case Study on Shoes Holic Veteran Padang). The results of the study can be seen the discount coefficient of 0.479 and has a positive influence or direction on purchasing decisions. These results indicate that with the increasing number of Shoes Holic Veteran Padang discounting will influence purchasing decisions, with a discount will encourage customers to make purchasing decisions, if Shoes Holic provides discounts that are large enough or often enough then consumers will be more interested in buying the products offered

\section{Effect of Atmosphere Against Store Purchase Decision (Case Study on Veterans Holic Shoes Padang)}

This study proves that Store Atmosphere have a significant positive influence on purchase decisions (Case Study on Shoes Holic Veteran Padang). The results of the study can be seen at 0.342 coefficient of Store Atmosphere and has no effect or a positive direction on purchasing decisions. The results show that with increasing Shoes Holic Veteran Padang do Store Atmosphere will affect customers in making purchasing decisions in this regard Store Atmosphere will increase the attractiveness of customers to visit and shopping in Shoes Holic.

\section{Conclusions}

Based on the analysis and discussion of the Effect of Viral Marketing, Promotions, Discounts and Store Atmosphere Purchasing Decision (Case Study on Shoes Holic Veteran Padang), it can be concluded viral Marketing, Promotions, Discounts and Store Atmosphere have significant and positive influence on the buying decision.

1. Based on Achievement Level Respondents (TCR), the lowest it can be concluded that the curiosity of consumers (curiosit) Shoes Holic Padang Veteran of the products featured in social media Shoes Holic Padang Veteran seem ordinary. Consumers are not interested in the content in social media Shoes Holic because it is tantamount to shoe products are sold on the sidewalk. For it is expected that management Padang Veteran Shoes Holic in providing content on social media to pay attention to the image and view the uploaded videos that consumers are interested in pictures and videos.

2. Based on Achievement Level Respondents (TCR), the lowest it can be concluded that the sale of personal (personal selling) Shoes Holic Veterans Padang in attracting consumers to be increased again. in the Airdirect interaction with consumers expected salesperson can serve well and answer questions and receive messages from consumers. Because of personal selling plays an important role in the marketing services and get feedback from consumers.

3. Based on Achievement Level Respondents (TCR), the lowest it can be concluded that the discounts given season Padang Veteran Shoes Holic cannot attract consumers to shop for products Shoes Holic Veteran Padang. For it is expected that the discounts given by Padang Veteran Shoes Holic not only in certain seasons, but also do a discount on weekdays so that consumers may be interested in the products Shoes Holic.

4. Based on Achievement Level Respondents (TCR), the lowest it can be concluded that the Exterior (Exterior Shop) Shoes Holic Veterans Padang in attracting consumers can be increased again. For that is expected to management Veteran Shoes Holic Padang to improve store atmosphere on the outside of the store to provide bright lighting, the color of the store in accordance with the target consumers, as well as the complementary music store update and store atmosphere that does not make consumers feel saturated.

\section{References}

Adelsar, Navid dan Khoshtinat, Behnaz. (2016). Critical factors and advantage factors influencing the implementation of viral marketing by considering the mediating role of Islamic marketing; a conceptual approach. Procedia Economics and Finance. 36: 433 - 440 
Berman, B. and Evans, Jr. (2013). Retail Management: A Strategic Approach. Edisi ke 12. England: Pearson.

Cindy Juwita. (2013). Store Atmosphere Pengaruhnya terhadap Keputusan Pembelian Kosumen di Texas Chicken Multimart II Manado. Jurnal EMBA. Vol. 1, No. 3.

Eltaj Mohammed M.A.H. (2017). Investigating effect of viral marketing on consumers purchasing decision (case study: the student of the administratife science college najran university). British Journal of Marketing Studies. Vol.5, No.4,pp. 63-73.

Kotler, Philip dan Amstrong, Gary. (2012). Principles of Marketing. Edisi ke 14. England: Pearson Education

Kotler, Philip, dan Kevin Lane Keller. (2009). ManajemenPemasaran, Edisike13, jilid 1\&2. Erlangga Jakarta:Erlangga

Lekhanya, Lawrence Mpele, (2014). The Impact Of Viral Marketing On Corporate Brand Reputation. International Business \& Economics Research Journal - March/April 2014 Volume 13, Number 2.

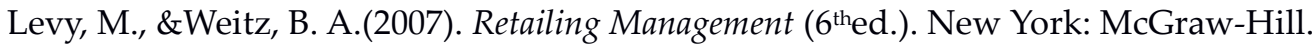

Natasya Putri, dkk. (2014). Pengaruh Viral Marketing Terhadap Kepercayaan Pelanggan dan Keputusan Pembelian. Jurnal Administrasi Bisnis (JAB). Vol. 25, No. 1.

Ristania dan Jerry S. Justianto. (2014). Analisis Pengaruh Harga, Promosi dan Viral Marketing Terhadap Keputusan Pembelian Pada "Online Shop" Nexian Melalui Facebook. Jurnal of Business Strategy and Execution, 2, 131-161.

Salome, Peter, et al. (2017). Multi-unit price promotions and their impact on purchase decisions and sales. European Journal of Marketing. Vol. 51 Issue: 5/6, pp.1049-1074

Skrob, John R. (2005). Open Source and Viral Marketing (The Viral Marketing Concept as a Model For Open Source Soaftware to Reach the Critikal Mass for Global Brand Awareness based on the Example of TYPHO3). University of Applied Science Kufstein, Austria.

Swanepoel, Celeste et.al. (2009) Virally inspired: A review of the theory of viral stealth marketing. Australasian Marketing Journal, Vol. 17, Iss.1. 